\title{
ROOT DISTRIBUTION OF IRRIGATED GRAPEVINE ROOTSTOCKS IN A COARSE TEXTURE SOIL OF THE SÃO FRANCISCO VALLEY, BRAZIL ${ }^{1}$
}

\author{
LUÍS HENRIQUE BASSOI², LEILSON COSTA GRANGEIRO ${ }^{3}$, \\ JOSÉ ANTONIO MOURA E SILVA³, EMANUEL ELDER GOMES DA SILVA ${ }^{3}$
}

\begin{abstract}
An experiment was carried out to determine the root distribution of four grapevine rootstocks (Salt Creek, Dogridge, Courdec 1613, IAC 572) in a coarse texture soil of a commercial growing area in Petrolina County, São Francisco Valley, Brazil. Rootstocks were grafted to a seedless table grape cv. Festival, and irrigated by microsprinkler. Roots were quantified by the trench wall method aided by digital image analysis. Results indicated that roots reached $1 \mathrm{~m}$ depth, but few differences among rootstocks were found. All of them presented at least $90 \%$ of the roots distributed until $0.6 \mathrm{~m}$ depth, with a greater root presence in the first $0.4 \mathrm{~m}$. The upper $0.6 \mathrm{~m}$ can be taken into account as the effective rooting depth for soil and water management.
\end{abstract}

Index terms: grapevine, root system, digital image analysis

\section{DISTRIBUIÇÃO RADICULAR DE PORTA-ENXERTOS DE VIDEIRAS IRRIGADAS EM UM SOLO DE TEXTURA ARENOSA DO VALE DO SÃO FRANCISCO}

RESUMO - Um experimento foi conduzido para se determinar a distribuição radicular de quatro porta-enxertos (Salt Creek, Dogridge, Courdec 1613, IAC 572) em um solo de textura arenosa, em um plantio comercial em Petrolina - PE, no Vale do São Francisco. Os portaenxertos foram enxertados com a cv. de uva de mesa sem sementes Festival, e irrigados por microaspersão. As raízes foram quantificadas pelo método da parede da trincheira auxiliado pela análise de imagem digital. Os resultados indicaram que as raízes atingiram $1 \mathrm{~m}$ de profundidade, mas poucas diferenças entre os porta-enxertos foram observadas. Cerca de $90 \%$ do sistema radicular de todos os portaenxertos estavam distribuídos até $0,6 \mathrm{~m}$ de profundidade, mas houve uma grande presença de raízes até $0,4 \mathrm{~m}$. A camada superficial de solo de $0,6 \mathrm{~m}$ pode ser considerada como a profundidade efetiva do sistema radicular para fins de manejo de solo e água.

Termos para indexação: videira, sistema radicular, análise de imagem digital

\section{INTRODUCTION}

The importance of rootstock evaluation in a specific growing area is due to the influence of site conditions. So, criteria such as phylloxera, phytophtora and nematodes infestation, soil type, chlorosis inducing power of the soil, soil depth, drought, water logging, salinity, and vigor conferred to the scion have been used to evaluate rootstocks (Delas, 1992; Southey, 1992). Other analyses about rootstock/scion interactions as partitioning of dry weight and nutrients (Williams \& Smith, 1991), root distribution and density (Southey \& Archer, 1988; Morano \& Kliewer, 1994), leaf water potential, yield, and berry composition (Ezzahouani \& Williams, 1995) have been also performed.

The spatial root distribution of grapevines is determined by the soil environment (Nagarajah, 1987; Morlat \& Jacquet, 1993), as well as by the practices that alter it (Van Hysteen, 1988). Differences in root distribution (Perry et al., 1983; Swanepoel \& Southey, 1989) and in root density (Southey \& Archer, 1988; Williams \& Smith, 1991) have been demonstrated among rootstocks within a given soil environment. In addition, it has been pointed out that edaphic conditions determine the distribution of roots in the soil profile while genetic factors determine the density of roots (Southey \& Archer, 1988; Williams \& Smith, 1991).

Each rootstock presents undesirable characteristics and only the local experimentation can determine with acceptable precision the most adapted for the specific site, and more than one rootstock is recommended for large areas (Pommer et al., 1997).

Hence, the aim of this study was to quantify the root distribution of four rootstocks grafted to seedless table grape in a specific soil condition of a commercial growing area at Petrolina County, in the São Francisco Valley, in the semi-arid region of northeastern Brazil.

\section{MATERIAL AND METHODS}

Root evaluation was performed in January 2000 at a commercial growing area in Petrolina County, in the São Francisco Valley, Brazil. Rootstocks Salt Creek, Dogridge, Courdec 1613, and IAC 572 were grafted to seedless table grape cv. Festival. The vineyard was planted in June 1995 with $3.5 \mathrm{~m}$ spacing between rows and $3.0 \mathrm{~m}$ between plants. Grapevines have been

1 (Trabalho 046/2001). Recebido: 19/02/2001. Aceito para publicação: 01/11/2001.

2 Researcher, Embrapa Semi-Árido, C. P. 23, 56300-970, Petrolina - PE, Brasil lhbassoi@cpatsa.embrapa.br

3 Fellowship holder from Brazilian National Council for Scientific and Technological Development - CNPq 
irrigated by one microsprinkler in the row and between two plants, with wetting pattern over all soil surface.

Trenches with $1 \mathrm{~m}$ depth and $6 \mathrm{~m}$ width were dug between plant rows to expose half system of two plants. For each rootstock, two trenches, i.e., four plants were analyzed, and the distance of trench wall to the trunk was $0.2 \mathrm{~m}$. Soil samples in each $0.2 \mathrm{~m}$ depth increment were collected to perform physical and chemical analyses in laboratory according to procedures described by Embrapa (1997). A thin layer of soil $(1-2 \mathrm{~cm})$ was carefully removed from the wall along the whole trench, and visible roots (generally with diameter larger than $1 \mathrm{~mm}$ ) were painted with white ink to enhance color contrast between the roots and the soil. A $3 \mathrm{~m} \times 1.5 \mathrm{~m}$ wire-wood frame with a grid of $0.2 \mathrm{~m} \times 0.2 \mathrm{~m}$ was pressed on the trench wall and pictures with a digital camera (resolution of $640 \times 480$ pixels) were taken from each $0.04 \mathrm{~m}^{2}$ area along the whole trench. Pictures were transferred to a computer as BMP files for analysis by the Integrated System for Root and Soil Coverage Analysis - SIARCS (Crestana et al., 1994). The variables root area $\left(\mathrm{A}_{\mathrm{r}}, \mathrm{cm}^{2}\right)$ and root length $\left(\mathrm{L}_{\mathrm{r}}, \mathrm{cm}\right)$ were measured and their means in each $0.2 \mathrm{~m} \times 0.2$ $\mathrm{m}$ were analyzed by T-test against depth and rootstock using a repeated measures design. This was necessary because the root variables value at one depth is not independent on the other one at the next depth (Morano \& Kliewer, 1994). The values of $\mathrm{A}_{\mathrm{r}}$ and $\mathrm{L}_{\mathrm{r}}$ were integrated in each $0.2 \mathrm{~m}$ soil layer to obtain their average fractional distribution over the entire soil profile, and the root diameter $\left(\mathrm{D}_{\mathrm{r}}, \mathrm{mm}\right)$ was estimated by the ratio $\mathrm{A}_{\mathrm{r}} / \mathrm{L}_{\mathrm{r}}$ (Bassoi et al., 2000). The correlation coefficients $(p<0.05)$ between both root variables in each $0.2 \mathrm{~m} \times 0.2 \mathrm{~m}$ and between averaged fractional distributions were also obtained.

\section{RESULTS AND DISCUSSION}

Taking into consideration both $\mathrm{A}_{\mathrm{r}}$ and $\mathrm{L}_{\mathrm{r}}$, rootstock Courdec 1613 was the one with greater amount of roots at $0-0.2$ and at 0.2-0.4 m depths, which means a more homogeneous distribution until $0.4 \mathrm{~m}$ depth, where most of the roots were presented for all rootstocks. In the first soil layer, Dog Ridge presented fewer roots, but in the second one it was similar to Courdec 1613. In 0.4-0.6 $\mathrm{m}$ and $0.6-0.8 \mathrm{~m}$ depths, basically there were no differences in the root distribution among rootstocks, while that at $0.8-1.0 \mathrm{~m}$ it was noted a smaller root presence in Courdec 1613 in comparison with others (Table 1). It should be mentioned that in Courdec 1613 trenches, the amount of organic matter was visibly higher, and the soil analysis showed that at 0 $0.2 \mathrm{~m}$ depth its content was $2.8 \%$, while in the other three ones it was around $0.6 \%$. Probably, this condition has contributed to a greater root proliferation in Courdec 1613 site at upper soil layer. Correlation coefficient between both variables was 0.813 , and $\mathrm{A}$ values of all rootstocks were plotted for a visual observation (Figure 1).

The correlation coefficient between $\mathrm{A}_{\mathrm{r}}$ and $\mathrm{L}_{\mathrm{r}}$ fractional distributions was 0.995 . So, only $\mathrm{A}_{\mathrm{r}}$ fractional distribution is presented. It is cleared up that almost all of the root systems were present until $0.6 \mathrm{~m}$ depth, although a greater amount was in the upper $0.4 \mathrm{~m}$ depth. $\mathrm{D}_{\mathrm{r}}$ estimation was smaller for Salt Creek, while it was greater for Dogridge, and in general, values presented little variation between soil depths (Table 2).

Inside the plant row, most of the roots from all rootstocks reached the distance of $1.1 \mathrm{~m}$ from the trunk, i.e., $80 \%$ for Salt Creek, $81 \%$ for Dogridge, $81 \%$ for Courdec 1613 , and $77 \%$ for IAC 572. Hence, roots from one plant seem to almost crossover with others from the neighbor plant due to growth characteristics, organic matter application, and wetting pattern of the microsprinklers.

As grapevine root distribution in the soil profile is dependent on edaphic conditions (Nagarajah, 1987; Morlat \& Jacquet, 1993), the soil depth with higher root presence has varied around $0.4 \mathrm{~m}$ (Nappi et al., 1985), $0.5 \mathrm{~m}$ (Padgett-Jonhson, 1999), $0.8 \mathrm{~m}$ (Stevens \& Douglas, 1994), $1.0 \mathrm{~m}$ (Araujo et al., 1995), and $2.4 \mathrm{~m}$ (Williams \& Smith, 1991). Some of the factors influencing it are the irrigation system, age of the plant, rootstock, spacing grid, and physical-chemical soil conditions. In this study, the 0.4 $\mathrm{m}$ soil depth presented a greater root presence for all rootstocks, and a sharp decreasing has occurred from this point to $0.6 \mathrm{~m}$. Below of this depth, the reduction was gradual. In addition, Bassoi et al. (1998) found out similar results about rooting depth of rootstock IAC 313 grafted to $\mathrm{cv}$. Italia also under irrigation and in a coarse texture soil of the São Francisco Valley. It is supposed that manure application (generally $20-40 \mathrm{~L}$ per vine), a common practice of the table grape crop system in the São Francisco Valley, has provided better root proliferation conditions on the upper soil layers. Morlat \& Jacquet (1983) also reported a higher grapevine root presence in a sandy soil horizon with higher organic matter content. According to Reichardt (1981), the main factors to few deep rooting in tropical soils are low $\mathrm{pH}$, high exchangeable aluminum, compaction, inadequate aeration, and low retention and transmission of water. In this study, soil texture in the $1 \mathrm{~m}$ profile was $84 \%$ of sand, $6 \%$ of silt and $10 \%$ of clay,

TABLE 1 - Means of root area $\left(\mathrm{A}_{\mathrm{r}}, \mathrm{cm}^{2}\right)$ and root length $\left(\mathrm{L}_{\mathrm{r}}, \mathrm{cm}\right)$ along the trench wall of four rootstocks grafted to cv. Festival as a function of soil depth.

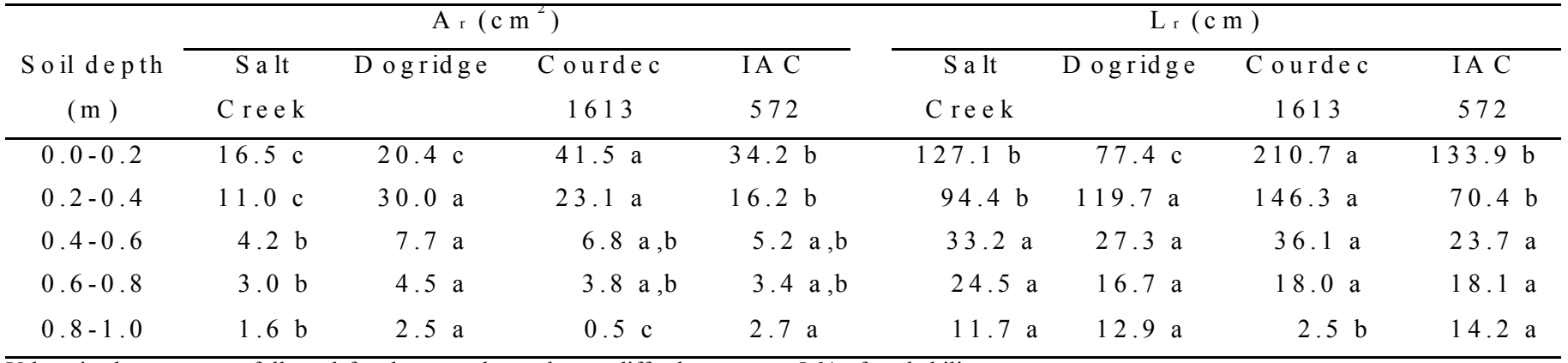

Values in the same row followed for the same letter do not differ by t-test at $5 \%$ of probability. 
TABLE 2 - Fractional distribution of root area $\left(A_{r}\right)$ and root diameter $\left(D_{r}\right)$ of four rootstocks grafted to cv. Festival, as a function of soil depth.

\begin{tabular}{|c|c|c|c|c|c|c|c|c|}
\hline \multirow{3}{*}{$\begin{array}{l}\text { Soil de pth } \\
(\mathrm{m})\end{array}$} & \multicolumn{4}{|c|}{ A r d istribution ( $\%)$} & \multicolumn{4}{|c|}{$\overline{\mathrm{D}} \mathrm{r}(\mathrm{m} \mathrm{m})$} \\
\hline & S a lt & D ogridge & Courdec & IA C & S a lt & D ogridge & Courdec & I A C \\
\hline & Creek & & 1613 & 572 & Creek & & 1613 & 572 \\
\hline $0.0-0.2$ & 45.6 & 31.3 & 55.2 & 55.1 & $1.3 \pm 0.9$ & $2.5 \pm 0.9$ & $2.0 \pm 0.9$ & $2.5 \pm 1.0$ \\
\hline $0.2-0.4$ & 30.3 & 46.1 & 30.6 & 26.1 & $1.2 \pm 0.1$ & $2.5 \pm 0.8$ & $1.8 \pm 2.1$ & $2.3 \pm 1.2$ \\
\hline $0.4-0.6$ & 11.5 & 11.8 & 9.0 & 8.4 & $1.3 \pm 0.1$ & $2.9 \pm 1.0$ & $2.1 \pm 0.7$ & $2.1 \pm 0.6$ \\
\hline $0.6-0.8$ & 8.2 & 6.9 & 4.5 & 6.1 & $1.3 \pm 0.2$ & $2.9 \pm 0.9$ & $2.1 \pm 1.3$ & $2.4 \pm 1.3$ \\
\hline $0.8-1.0$ & 4.3 & 3.9 & 0.7 & 4.3 & $1.3 \pm 0.2$ & $2.8 \pm 0.8$ & $1.9 \pm 1.1$ & $2.2 \pm 0.9$ \\
\hline
\end{tabular}
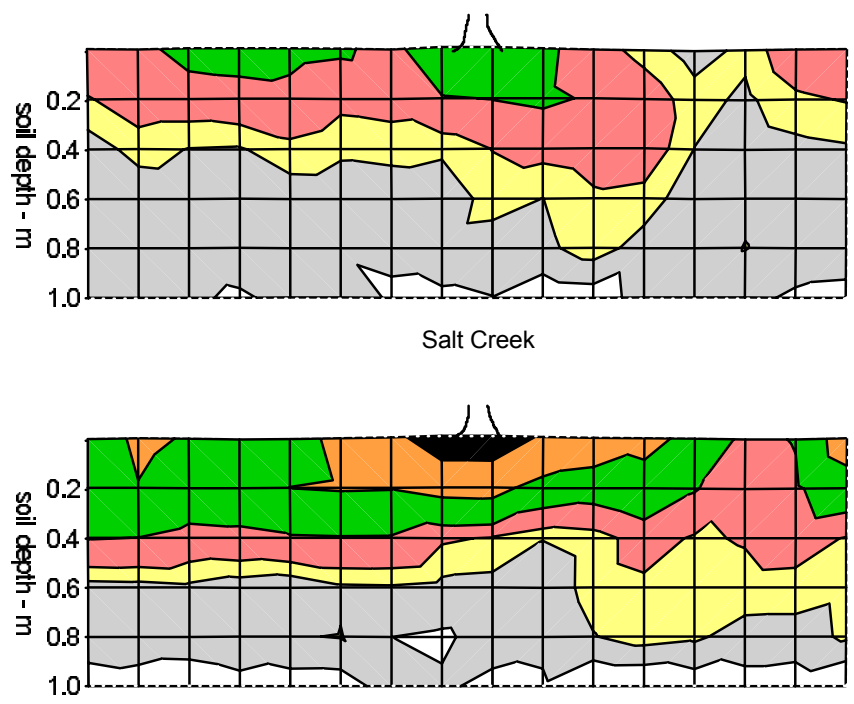

Courdec 1613

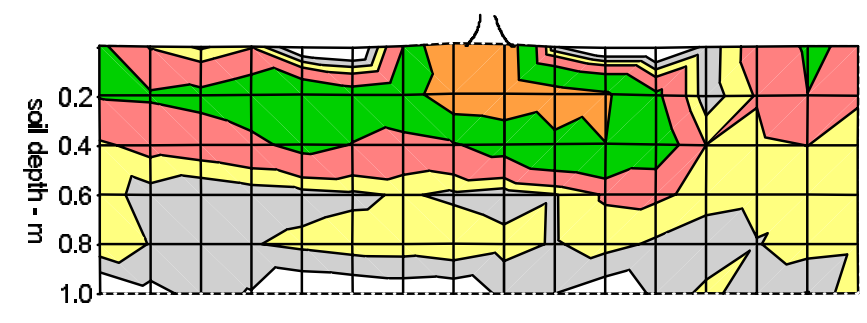

Dogridge

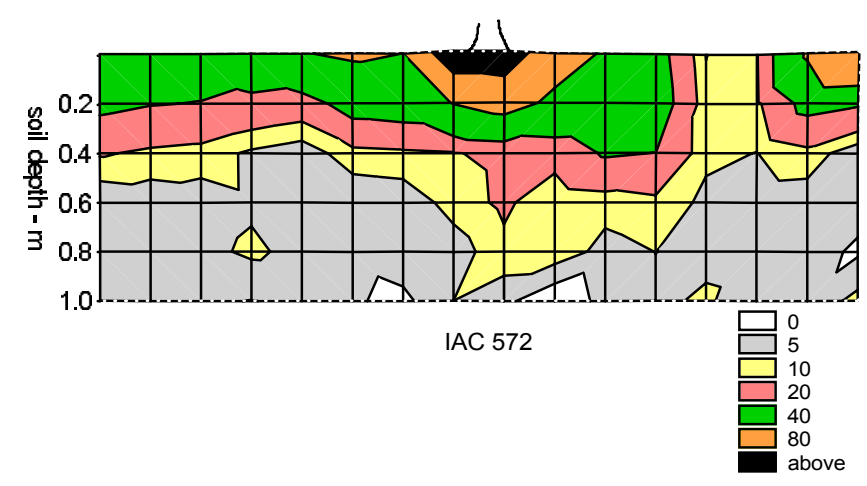

FIGURE 1 - Front view of the root area $\left(\mathrm{cm}^{2}\right)$ of grapevine rootstocks over the trench wall. Values in legend mean the maximum one in a root area interval.

and water holding capacity at $0.1 \mathrm{~atm}$ was less than $0.110 \mathrm{~cm}^{3} . \mathrm{cm}^{-}$ ${ }^{3}$. Soil $\mathrm{pH}$ was $6.7,7.7,7.3,5.6$, and 4.4 at $0-0.2,0.2-0.4,0.4-0.6$ , 0.6-0.8 and 0.8-1.0 m depth, respectively, while organic matter content was less than $1 \%$ in the three first layers. As pointed out by Bassoi et al. (2000), correlation coefficients found between root variables were high, and they were better for the average fractional distribution. Greater percentage of grapevine roots have been found within $\mathrm{D}_{\mathrm{r}}<0.5 \mathrm{~mm}$ (Van Zyl, 1988), $\mathrm{D}_{\mathrm{r}}<1 \mathrm{~mm}$ (Morlat \& Jacquet, 1993) and $\mathrm{D}_{\mathrm{r}}<2 \mathrm{~mm}$ (Morano \& Kliewer, 1994; PadgettJohnson, 1999). So, $D_{r}$ estimation found in this study was in accordance with others.

\section{CONCLUSION}

In a coarse texture soil of the São Francisco Valley, Brazil, grapevine rootstocks Salt Creek, Dogridge, Courdec 1613 and IAC 572 grafted to $\mathrm{cv}$. Festival and under microsprinkler irrigation, presented a greater root presence until $0.4 \mathrm{~m}$ depth, with a sharp decreasing from this point to $0.6 \mathrm{~m}$. As around $90 \%$ of the roots were distributed until the upper $0.6 \mathrm{~m}$ soil, this soil layer should be taken into consideration as the effective rooting depth for soil and water management. In the horizontal direction and inside the plant row, at least $80 \%$ of the roots were found until the distance of $1.1 \mathrm{~m}$ from the trunk.

\section{REFERENCES}

ARAUJO, F., WIILIAMS, L. E., GRIMES, D. W., MATTHEWS, M. A. A comparative study of young "Thompson Seedless" grapevines under drip and furrow irrigation. I. Root and soil water distributions. Scientia Horticulturae, v.60, n.3-4, p.235-249, 1995.

BASSOI, L. H., JORGE, L. A. C., CRESTANA, S. Root distribution analysis of irrigated grapevines in Northeastern Brazil by digital image processing. In: WORLD CONGRESS OF SOIL SCIENCE, 16., 1998, Montpellier. Proceedings... Montpellier: ISSS, 1998. 7p. (CD Rom).

BASSOI, L. H., SILVA, J. A. M. E, ALENCAR, C. M. de, JORGE, L. A. de C., HOPMANS, J.W. Digital image analysis of root 
distribution towards improved irrigation water and soil management: grapevine and date palm study cases. In: ASAE ANNUAL MEETING, 2000, Milwaukee. Papers... Milwaukee: ASAE, 2000. 6p. (paper 002032).

CRESTANA, S., GUIMARÃES, M. F., JORGE, L. A. C., RALISH, R., TOZZI, C. L., TORRE, A., VAZ, C. M. P. Avaliação da distribuição de raízes no solo auxiliada por processamento de imagens digitais. Revista Brasileira de Ciência do Solo, Campinas, v.18, n.3, p.365-371, 1994.

DELAS, J. J. Criteria used for rootstock selection in France. In: ROOTSTOCK SEMINAR, A WORLDWIDE PERSPECTIVE, 1992, Reno. Proceedings... Davis: ASEV, 1992. p.1-14.

EMBRAPA. Centro Nacional de Pesquisa de Solos. Manual de métodos de análise de solo. 2. ed. Rio de Janeiro: Embrapa-SPI, 1997. 212p.

EZZAHOUANI, A., WILLIAMS, L. E. The influence of rootstock on leaf water potential, yield, and berry composition of Ruby Seedless grapevines. American Journal of Enology and Viticulture, Davis, v.46, n.4, p.559-563, 1995.

MORANO, L., KLIEWER, W. M. Root distribution of three grapevine rootstocks grafted to Cabernet Sauvignon grown on a very gravelly clay loam soil in Oakville, California. American Journal of Enology and Viticulture, Davis, v.54, n.3, p. 345-348, 1994.

MORLAT, R., JACQUET, A. The soil effects on the grapevine root system in several vineyards of the Loire valley (France). Vitis, Siebeldingen, v.32, n.1, p.35-42, 1993.

NAGARAJAH, S. Effects of soil texture on the rooting patterns of Thompson Seedless vines on own roots and on Ramsey rootstock in irrigated. American Journal of Enology and Viticulture, Davis, v.38, n.1, p.54-59, 1987.

NAPPI, P., JODICE, R., LUZZATI, A., CORINO, L. Grapevine root system and VA mycorrhizae in some soils of piedmont (Italy). Plant and Soil, The Hague, v.85, n.2, p.205-210, 1985.

PADGETT-JOHSON, M. Vine water relations, gas exchange, growth and root distribution of several Vitis species under irrigated and non-irrigated conditions. Davis, 1999.420p. Thesis, University of California, Davis.
PERRY, R. L., LYDA, S. D., BOWEN, H. H. Root distribution of four Vitis cultivars. Plant and Soil, The Hague, v. 71, n.1, p. 63$74,1983$.

POMMER, C. V.; PASSOS, I. R. S.; TERRA, M. M.;PIRES, E. J.P.. Variedades de videiras para o Estado de São Paulo. Campinas: Instituto Agronômico, 1997. 59p. (Boletim Técnico, 166)

REICHARDT, K. Soil physico-chemical conditions and the development of roots. In: R. S. RUSSEL, R. S., IGUE, K., MEHTA, Y. R. (Ed.) The soil/root system in relation to brazilian agriculture. Londrina: IAPAR, 1981, p.103-114.

SOUTHEY, J. M. Grapevine rootstock performance under diverse conditions in South Africa. In: ROOTSTOCK SEMINAR, A WORLDWIDE PERSPECTIVE, 1992, Reno. Proceedings... Davis:ASEV, 1992.p.27-51.

SOUTHEY, J. M.; ARCHER, E. The effect of rootstock cultivar on grapevine root distribution and density. In: VAN ZYL, J L. (Comp.). The grapevine root and its environment. Pretoria: Viticultural and Oenological Research Institute, 1988, chapter 5, p.57-73.

STEVENS, R. M.; DOUGLAS, T. Distribution of grapevine roots and salt under drip and full-ground cover microjet irrigation systems. Irrigation Science, Heidelberg, v.15, n.4, p.147-152, 1994.

SWANEPOEL, J. J., SOUTHEY, J. M. The influence of rootstock on the rooting pattern of the grapevine. South African Journal for Enology and Viticulture, Pretoria, v.10, n.1, p.23-28, 1989.

VAN HYSTEEN, L. Grapevine root growth in response to soil tillage and root pruning practices. In: VAN ZYL, J L. (Comp.). The grapevine root and its environment. Pretoria: Viticultural and Oenological Research Institute, 1988, chapter 4, p.45-55.

VAN ZYL, J. L. Response of grapevine to soil water regimes and irrigation systems. In: VAN ZYL, J L. (Comp.). The grapevine root and its environment. Pretoria: Viticultural and Oenological Research Institute, 1988, chapter 1, p.30-43.

WILLIAMS, L. E., SMITH, R. J. The effect of rootstock on the portioning of dry weight, nitrogen and potassium, and root distribution of Cabernet Sauvignon grapevines. American Journal for Enology and Viticulture, Davis, v.42, n.2, p.118-122, 1991. 